\title{
The Impacts of Financial Inclusion on Economic Development: Cases in Asian-Pacific Countries ${ }^{1}$
}

\author{
Dinh Thi Thanh Van \\ Ph.D., Faculty of Finance and Banking, Vietnam National University \\ University of Economics and Business, Hanoi, Vietnam \\ e-mail:vandtt@vnu.edu.vn or dinhthanhvan@gmail.com
}

\author{
Nguyen Ha Linh \\ Research Assistant, Faculty of Finance and Banking, Vietnam National University \\ University of Economics and Business, Hanoi, Vietnam \\ e-mail: linhnh27@gmail.com
}

\begin{abstract}
Financial inclusion efforts seek to ensure that all members of an economy can have access to and effectively use appropriate financial services. Improving financial inclusion has become a significant concern for developed and developing countries alike. There are many indicators of financial inclusion, the most elementary of which includes having an account in a financial institution. This paper will evaluate the impact of indicators of financial inclusion on economic development. The result shows that correlations exist between large numbers of bank branches, ATMs, domestic credit in the private sector and the increased rate of development in the economy. People will gain a more prosperous life due to this development. The paper also provides recommendations for the governments of developing countries to improve financial inclusion.
\end{abstract}

Keywords: Asia, account, ATMs, bank, credit, economic development, financial inclusion

JEL: A10

1 This article is funded by the research project QG 16.84 of Vietnam National University, Hanoi. 


\section{Introduction}

Financial inclusion, which is recognized as playing a crucial role in reducing income inequality, is becoming a priority for policymakers globally (World Bank 2014, pp. 3-5). It can make possible 7 out of the 17 sustainable development goals provided by the United Nations. Besides being valuable to the economy of a country, financial inclusion also benefits individuals. Being included in the formal financial system assists people in making daily transactions, including paying and receiving; making investments; saving for future plans and recurring expenses; or preparing for unexpected events. In general, their welfare will be improved.

Having at least an account in a financial institution is the first step toward broader financial inclusion as it allows people to make transactions and save money. According to the Findex report in 2014, in the three years beginning from 2011, there was an increase of $11 \%$, or 700 million, in the number of adults who have at least one account. However, the number of unbanked people was at more than 2 billion - around half of the total adult population. CGAP estimated that in $2007,80 \%$ of the population in less developed countries could not have access to formal financial services. A lack of education, awareness, or even geographical difficulties may become barriers, leaving people with no choice but to resort to risky informal financial systems (Wang'oo 2008, pp. 3-4).

Therefore, this paper will illustrate the impacts of financial inclusion on economic development by using the most suitable indicators.

\section{Literature review}

\section{Financial inclusion}

Financial inclusion is defined as the ability to provide financial services at a reasonable cost (Claessens 2006, p. 210), which ensures the availability and usage of formal financial system (Sarma 2008, p. 3) to people in different statuses by implementing innovative approaches. These include financial awareness and financial education to promote financial well-being, as well as economic and social inclusion. Moreover, financial inclusion is also a tool which helps individuals access appropriate financial products and services (Scottish Executive 2005, p. 4).

Financial inclusion was found to allow individuals and businesses to manage their money daily, effectively as well as safely, and to plan for the future and to cope with financial pressures through financial management (HM Treasury 2007, p. 84). It also reduces the short-term fluctuation of income and expenses and takes advantage of long-term opportunities to solve financial difficulties which result from unexpected events.

Financial inclusion plays an important role in creating jobs, improving access to credit for consumption and production purposes, increasing household expendi- 
ture, preventing exploitation caused by the informal financial system, increasing income and assets and developing human resources, as well as improving living standards. Therefore, it may lead to poverty reduction and economic and social development (Das 2012, p. 116).

Moreover, through financial inclusion, the poor will be able to manage their daily needs as well as discover investment opportunities which can improve their income and assets (Stein 2010, p. 5). If barriers to financial inclusion, for example, high charges, minimum balance requirement, documentation requirements, or lack of financial literacy, are reduced, then it can expand the use of formal saving products by low-income households and can stimulate household investment; therefore, the growth of developing countries are contributed (Beck 2016, p. 6).

\section{Economic development}

There is a difference between economic development and economic growth. The latter term refers to an increase in the total output of a country as well as an increase in the productivity that an economy can produce in a specific period compared to another (Julie 2013, pp. 2-3). Generally, economic growth can be measured by the increase in the percentage of gross domestic product (GDP) after adjusting the inflation rate.

However, GDP also has some weaknesses when reflecting an economy. It only refers to the quantity rather than the quality of the goods and services produced and the penetration of new products replacing obsolete ones. This usually happens with technology products. Several activities in the underground economy, such as money laundering and unlisted products, are not considered parts of GDP. Moreover, GDP cannot reflect external impacts such as environmental pollution, which can cause negative effects on employees' health and productivity as well as the quality of the products. Therefore, economic development will be mentioned in the research to offset the above weaknesses.

Economic development is the relationship between economic growth and financial depth as well as the strategies and models proposed to achieve complementarities similar to those of developed economies (Onaolapo 2015, p. 13). It may also enhance human development (Recep 2012, p. 2). Ease of access to financial development has a positive impact on the poor, thereby reducing inequalities and increasing income.

Sen (1983, p. 60) believed that economic development means sustainable and co-operative efforts between policymakers and communities to increase regional living standards as well as economic well-being. It involves developing human resources, vital infrastructure, regional competitiveness, sustainable environment, social inclusion, healthcare, security and literacy. However, in research published in 1999, Sen referred to economic development as reducing the inadequacy which had many dimension of poverty, including famine, illiteracy, illness, poor conditions, powerlessness, insecurity and lack of accommodation (Narayan et al. 2000, pp. 4-5). In summary, the purpose of economic development is to reduce inequalities and unemployment. 
Sampson (2012, pp. 4-5) defined economic development as separate goals, the most prevalent of which are creating jobs and wealth as well as the improvement of living standards. Economic development is also described as a process that affects economic growth and restructuring in order to improve the economic welfare of a community. Overall, economic development includes three primary areas: controlling inflation, jobs and sustainable growth, with the main goal to increase the economic welfare of a community through efforts that require creating and securing jobs, upgrading the tax base and improving the quality of life.

\section{The relationship between financial inclusion and economic development}

Financial inclusion plays an important role in economic development, especially in terms of GDP growth and in reducing inequality and poverty in any country. The flexibility of financial inclusion is difficult to measure as it improves the ability of low-income families to access finance. Furthermore, firms and households can also have the opportunities to boost their income and self-reliance, positively affecting the economic development of a country. Being unable to access formal financial products and services may result in a loss of development opportunities, further poverty and cost to access.

A country with a developed financial system that is accessible to people can reduce the cost of information and transactions. Such a system will have impacts on savings and the long-term growth rate, investment decisions, and technological innovation.

Andreoni et al. (2008, pp. 13-14) said that being unable to access financial services strongly correlates with financial exclusion, which is related to poverty and inequality. In other words, a person or a region will be excluded in society if they are unemployed, lack skills, have a low income, are poor, or have an unstable surrounding environment or bad health. All of the above problems can result in family depression. Consequently, social disparity becomes more extreme, the rich become richer, the poor become poorer, and national economic development is affected.

Therefore, financial inclusion is crucial in narrowing the gap between the rich and the poor in society. Each country will have different financial inclusion policies that best suit their economy and social and cultural traits, with the same goal to develop the economy and reduce inequality.

\section{Research methodology}

The research process has two stages: the preliminary research and the official research. The first step is to search for and select relevant topic materials, then collect the reliable sources of data for use. Based on a theoretical basis, the research model used in this paper was developed. 
Wang'oo (2008, pp. 50-52) proved that there was a positive relationship between financial inclusion and economic development, meaning that increasing financial inclusion is synonymous with economic development. However, the research observation was only in Kenya for seven years (2005-2011). Therefore, this paper will evaluate the relationship among 23 Asian countries from 2010 to 2015.

The research will be based on a quantitative method, running a model by using the STATA12 program to determine the impact of financial inclusion on economic development. The model consists of one dependent variable and four independent variables, which are built on relevant studies.

The dependent variable is the Human Development Index (HDI) - representing economic development - as measured by UNDP.

The independent ones represent financial inclusion, including:

- The number of bank branches per 100,000 adults (branches);

- The number of ATMs per 100,000 adults (atm);

- Domestic credit to the private sector (\% of GDP) (credit);

- Broad money per GDP (m2).

All of these were collected by the World Bank. Drawing on previous studies on the use of HDI (Wang'oo 2008, p. 35), broad money and domestic credit to the private sector (Okoye, 2017), the model developed in this research is as follows:

In the model, the branches and atm variables have a larger index compared to the others, so both of them are assigned with a log to avoid bias in the result. The statistical observations are shown in Table 1.

Table 1. Statistical observations

\begin{tabular}{|l|c|c|c|c|c|}
\hline Variables & $\begin{array}{c}\text { Number } \\
\text { of observations }\end{array}$ & Average value & Standard Error & $\begin{array}{c}\text { Minimum } \\
\text { value }\end{array}$ & $\begin{array}{c}\text { Maximum } \\
\text { value }\end{array}$ \\
\hline year & 138 & & & 2010 & 2015 \\
\hline hdi & 138 & 0.72233 & 0.14343 & 0.454 & 0.939 \\
\hline branches & 138 & 13.47601 & 8.42543 & 1.49 & 34.14 \\
\hline atm & 138 & 56.48014 & 65.75378 & 0.02 & 290 \\
\hline credit & 138 & 94.67 & 76.82851 & -2.56 & 357.32 \\
\hline $\mathrm{m} 2$ & 138 & 100.32 & 74.08173 & 23.57 & 362.86 \\
\hline
\end{tabular}

Source: author's own calculations.

The hypotheses are:

H0_1: The model has no meaning; there is no impact of financial inclusion on economic development;

H1_1: The model has a meaning; financial inclusion has an impact on economic development;

H0_2: The number of banking branches per 100,000 adults does not affect economic development; 
H1_2: The number of banking branches per 100,000 adults affects economic development;

H0_3: The number of ATMs per 100,000 adults does not affect economic development;

H1_3: The number of ATMs per 100,000 adults affects economic development;

H0_4: Domestic credit to the private sector (\% of GDP) does not affect economic development;

H1_4: Domestic credit to the private sector (\% of GDP) affects economic development;

H0_5: Broad money per GDP does not affect economic development;

H1_5: Broad money per GDP affects economic development.

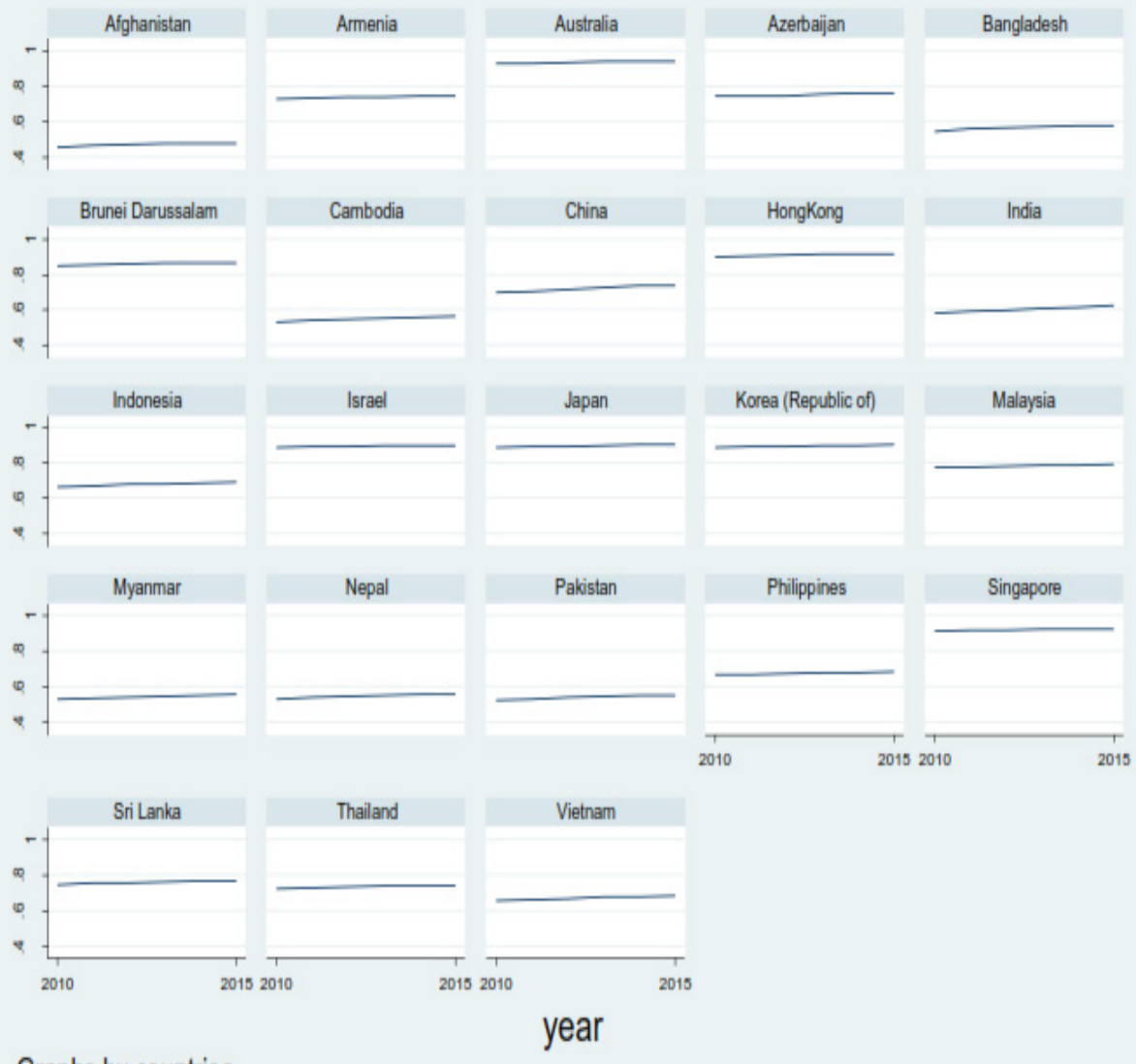

Graphs by countries

Chart 1. Human development index by country

Source: author's own calculations, drawn by STATA. 


\section{Result}

Comparing the result among OLS, REM and FEM regression.

Table 2. OLS, REM, FEM regression comparison

\begin{tabular}{|c|c|c|c|}
\hline \multirow{2}{*}{ Variables } & \multicolumn{3}{|c|}{ Beta } \\
\hline & OLS & REM & FEM \\
\hline Logbranches & 0.05445 & 0.02296 & 0.01749 \\
\hline Logatm & 0.04214 & 0.00546 & 0.00598 \\
\hline Credit & -0.00012 & 0.00047 & 0.00045 \\
\hline $\mathrm{m} 2$ & 0.00055 & $3.46 e-06$ & -0.00001 \\
\hline R square $\left(R^{2}\right)$ & 0.7654 & 0.6135 & 0.6054 \\
\hline
\end{tabular}

Source: author's own calculations.

Using the Breusch and Pagan test to select between OLS and REM, p-value $=0.0000<0.5$ so using REM regression has more significance than OLS.

Next, the Hausman test is used to evaluate the effect between REM and FEM, p-value $=0.0000<0.05$ so using FEM will have a better result than REM.

The Wald and Woolridge tests show that there are heteroscedasticity and autocorrelation in the model. According to the VIF test, there is no multicollinearity among independent variables.

Table 3. VIF test result

\begin{tabular}{|l|c|}
\hline \multicolumn{1}{|c|}{ Variables } & VIF \\
\hline logbranches & 2.98 \\
\hline logatm & 3.22 \\
\hline credit & 3.80 \\
\hline m2 & 3.34 \\
\hline Mean VIF & 3.33 \\
\hline
\end{tabular}

Source: author's own calculations.

Consequently, the research will use the Fixed Effect Model; the regression result is shown in Table 4.

Table 4. FEM regression result

\begin{tabular}{|l|c|c|c|c|}
\hline \multicolumn{1}{|c|}{ Variables } & Coefficients & Standard Error & T-statistic & p-value \\
\hline logbranches & 0.01749 & 0.00801 & 2.18 & 0.031 \\
\hline Logatm & 0.00598 & 0.00203 & 2.94 & 0.004 \\
\hline Credit & 0.00045 & 0.00007 & 6.52 & 0.000 \\
\hline m2 & -0.00001 & 0.00007 & -0.16 & 0.870 \\
\hline
\end{tabular}

Source: author's own calculations. 


\section{Conclusion}

The P-value of the model $=0.0000<0.05$ so the model is statistically significant. $\mathrm{R}^{2}$ overall $=0.6054$, which indicates that the model can explain $60.54 \%$ of the subject being researched. This number shows that economic development is also influenced by many other factors besides financial inclusion. Based on the result, there is an insufficient basis to reject hypothesis H0_5 $\left(\beta_{4}=0\right)$.

With a 95\% confidence level, the study concludes that three out of the four independent variables have an impact on economic development: the number of banking branches per 100,000 adults, the number of ATMs per 100,000 adults and the Domestic credit to private sector (\% to GDP), confirming hypotheses H1_2, H1_3 and H1_4.

Based on the coefficients in Table 4:

- With a $1 \%$ increase in the number of bank branches per 100,000 adults, economic development will rise by an average of $0.017 \%$;

- With a $1 \%$ increase in the number of ATMs per 100,000 adults, economic development will rise by an average of $0.006 \%$;

- With a $1 \%$ increase in domestic credit to the private sector to GDP, economic development will rise by an average of $0.00045 \%$.

In fact, a larger the number of bank branches and ATMs correlates with increased ease of access to formal financial sources for the public; thus, communication about financial services will be promoted. The result is that people will become more knowledgeable about finance, especially when it comes to distinguishing between the different financial products provided. However, the opposite is not necessarily true. A decrease in the number of bank branches and ATMs might depend on the policy of the financial institutes as they want to reduce the number to concentrate on online services such as e-mobile, internet banking and so on. Therefore, this reduction may not have an impact on economic development.

\section{Recommendations}

According to the results of the research model, the governments in developing countries need to promote the level of financial inclusion, especially in improving ease of access through the number of bank branches and ATMs and domestic credit provided.

Firstly, the governments of developing countries should expand the bank branches and ATMs to rural areas in order to give people an opportunity to access financial services without spending too much time and money. Financial education strategies should also be provided to every age group. For example, the governments may apply the Japanese approach in education by inviting retired people in the finance and banking sector to come to schools and villages to teach people about basic knowledge of financial products and services. By doing this, people will have the best source of formal financial knowledge, significantly improving national financial literacy. 
Secondly, the government can create opportunities for startups in the e-commerce business field by promoting the use of online transactions instead of cash. Vietnam's heavy dependency of cash for transactions makes point of sale (POS) devices less popular. On the other hand, there are many stores that have not install POS devices, opting instead for the traditional payment method of cash, causing inconvenience for customers who prefer card transactions.

Thirdly, the developing country's governments should also consider establishing centralized management of ATMs which are outside the branches of commercial banks as well as an organizing entity in the form of a joint stock company that shares the responsibility in governing and monitoring these ATMs. This company would be responsible for managing the ATMs in terms of ownership, development strategies, exploitation, operation, maintenance and upgrades. This centralized management model aims to optimize operating processes and the funding process. The model will be expanded to include other banks once its effectiveness has been proven.

Finally, besides expanding brick-and-mortar banks, another effective method to increase financial access is to promote the use of mobile banking as the rapid development of mobile technology creates a huge opportunity for financial inclusion. With an inexpensive feature phone, almost all people - including those who live in remote areas - can have easy access to credit, savings and insurance. Therefore, governments should issue regulatory policies which enhance the collaboration between financial access and mobile networks.

\section{References}

Anderloni, L., Bayot, B., Błędowski, P., Iwanicz-Drozdowska, M., \& Kempson, E. (2008), Financial Services Provision and Prevention of Financial Exclusion. European Commission.

Beck, T. (2016), Financial Inclusion - Measuring progress and progress in measuring.

Claessens, S. (2006), Access to Financial Services: A Review of the Issues and Public Policy Objectives. Oxford Journals, 207-240.

Das, K. (2012), Financial Inclusion - A Gateway to Sustainable Development for the Impoverished, "Journal of Rural Development", 115-128.

Demirguc-Kunt, A., Klapper, L., Singer, D., \& Oudheusden, P.V. (2014), The Global Findex Database 2014.

HM Treasury (2007), Meeting the Aspirations of the British People. London: HM Treasury.

Julie, O. (2013), The Relationship between Financial Inclusion and GDP Growth in Kenya.

Okoye, L.U. (2017), Financial Inclusion as a Strategy for Enhanced Economic Growth and Development, "Journal of Internet Banking and Commerce", Vol. 22, No. S8. 
Onaolapo, A.R. (2015), Effects of Financial Inclusion on the Economic Growth of Nigeria (1982-2012), "International Journal of Business and Management Review", Vol. 3, No. 3, 11-28.

Narayan, D., Patel, R., Schafft, K., Rademacher, A., Schulte, S.K. (2000), Voices of the Poor: Can Anyone Hear Us? New York: OUP.

Recep, Y. (2012), Financial Inclusion and Economic Development: A Case Study of Turkey and A Cross-Country Analysis. All These Paper 1352.

Sampson, D. (2012), Definitions of Economic Development. International Economic Development Council (IEDC).

Sarma, M. (2008), Index of Financial Inclusion. ICRIER Working Paper.

Scottish Executive (2005), Financial Inclusion Action Plan. Scottish Executive.

Sen, A.K. (1983), Development: Which Way Now? Economic Journal 93: 757-60.

Sen, A.K. (1999), Development adds Freedom. New York: Alfred A. Knopf.

Stein, P. (2010), Inclusive Finance. Korea-World Bank High-Level Conference on Post-Crisis Growth and Development. Busan, Korea: World Bank.

Wang'oo, E.W. (2008), The Relationship between Financial Inclusion and Economic Development in Kenya. University of Nairobi.

World Bank (2014), Global Financial Development Report: Financial Inclusion.

World Bank (2014), The Global Findex Database 2014.

\section{Streszczenie}

\section{Wpływ włączenia finansowego na rozwój gospodarczy: przykłady krajów Azji i Pacyfiku}

Działania na rzecz włączenia finansowego mają na celu zapewnienie wszystkim podmiotom funkcjonującym w gospodarce dostępu do odpowiednich usług finansowych i możliwości ich efektywnego wykorzystania. Zwiększenie włączenia finansowego stało się poważnym problemem zarówno dla krajów rozwiniętych, jak i rozwijających się. Istnieje wiele wskaźników włączenia finansowego, z których najbardziej podstawowym jest posiadanie konta w instytucji finansowej. Niniejszy artykuł ma na celu ocenę wpływu wskaźników włączenia finansowego na rozwój gospodarczy. Wyniki badań pokazują, że istnieją korelacje między dużą liczbą oddziałów banków, bankomatów, kredytu krajowego w sektorze prywatnym a wzrostem tempa rozwoju gospodarki. Rozwój ten umożliwi wzrost poziomu życia ludności. W artykule przedstawiono także zalecenia dla rządów krajów rozwijających się służące zwiększeniu włączenia finansowego.

Słowa kluczowe: Azja, konto, bankomaty, bank, kredyt, rozwój gospodarczy, włączenie finansowe 